\title{
THE EFFECT OF HEALTH EDUCATION ABOUT MENARCHE ON ANXIETY IN FACING MENARCHE IN 5TH AND 6TH GRADE STUDENTS
}

\author{
Surya Mustika Sari ${ }^{*}$, Henny Vidia Effendy ${ }^{1}$ \\ ${ }^{1}$ STIKES Dian Husada Mojokerto \\ *Correspondence: \\ Surya Mustika Sari \\ Email: surya.mustikasari@gmail.com
}

\begin{abstract}
Background: Important events during puberty are menstruation or menarche is a sign of sexual maturity. The causes of young men and women are not aware of their health problems, especially regarding menarche, this causes young women to have an understanding of menarche and lead to anxiety in the face of menarche in adolescent's daughter.

Objectives: This study aimed to determine the effect of health education about menarche on anxiety in facing menarche in 5th and 6th grade students at SDIT Permata Mulia.

Methods: This study design using pre-experimental design with one group pre-post-test design. Sampling method using Non-Probability Sampling with saturated sampling type. Samples taken as many as 28 responders on V and VI graders at SDIT Permata Mulia. The research data using a questionnaire. The data were analysed using the Wilcoxon test with a significance level of 0.05 .

Results: Anxiety student before being given health education about menarche mostly moderate anxiety at (53.6\%). While anxiety after students are given health education about menarche, mostly mild anxiety $(57.1 \%)$. Statistical test results obtained $\rho=0.00<\alpha=0.05$ then $\mathrm{H} 0$ is rejected and $\mathrm{H} 1$ is accepted, which means that there is a difference between health education about grade V and VI in SDIT Permata Mulia.

Conclusion: Seeing the results of this study about health education about menarche can help in reducing female anxiety in the face of menarche, the role of parents and educators is needed in providing an explanation of menarche to children in grades V and VI aged 11-12 years including maintaining personal hygiene in genital, provide knowledge to students that menarche will occur in all women.
\end{abstract}

Key words: Health education, Menarche, Anxiety.

\section{INTRODUCTION}

Adolescence or puberty is a period of transition or transition from childhood to adulthood marked by changes in physical, psychological, and psychosocial aspects. An important event at puberty is menstrual symptoms or menstruation for the first time (menarche), which is a sign of sexual maturity (Dariyo, 2004). During this time some people feel taboo to talk about menstrual problems in the family, so that early adolescents lack sufficient knowledge and attitude about physical and psychological changes related to menarche. Mental readiness is needed before menarche because of feelings of anxiety and fear will arise, besides, also lack of knowledge about self-care needed during menstruation (Proverawati and Misaroh, 2009). Problems with young women are the lack of response and information from parents and the role of health workers as 
educators in providing information about menarche, so health education is rarely carried out regarding signs of puberty, especially regarding menarche, this causes young women to lack understanding about menarche. and cause anxiety in dealing with menarche in young women.

In American puberty among young women between 12 years and 12.5 years, in the UK the average age of menarche is 13 years, while the age of menarche in Indonesia varies between 10-16 years (Wiknjosastro, 2005). Based on data from Basic Health Research (Riskesdas) in 2016 of 91,711 samples of women aged 10-59 years, $37.5 \%$ experienced menarche at age 13-14 years. Based on another study by Khoiriyah (2014) of 40 respondents there were $2.50 \%$ experiencing mild anxiety levels, $20.00 \%$ experiencing moderate anxiety levels, and $77.50 \%$ experiencing severe levels of anxiety in the face of menarche. Based on preliminary study on 2018 in the grader V and VI in SD IT Permata Mulia 2217 students are students who have not experienced menarche Most students do not understand about menarche and they said they were anxious aboutfacing menarche. Increasingly, the average age of menarche is getting early, the better the nutritional condition accelerates the body's readiness for menstruation. In addition, info about sex that is more easily obtained also triggers the brain to immediately activate sexual hormones. These various disorders and difficulties can directly or indirectly affect a child's physical or psychological condition. Moreover, if the person concerned does not understand well about menarche and what must be done to overcome the problems that occur (Rubianto, 2002). In this case, sufficient knowledge about menarche is needed, such knowledge can be obtained through health education. Health education as a set of experiences that support the habits, attitudes, and knowledge related to the health of individuals, communities and races (Wood, 1926 in Suliha 2002). But health education about menarche is very rarely found by young women so that it can cause symptoms of anxiety. Anxiety is very much related to feelings of discomfort and anxiety, in young women who experience menarche without sufficient knowledge will experience various anxiety. With sufficient knowledge it will affect the reduced level of anxiety so that children will be ready to face menarche. Lack of information about menarche in adolescent girls can have an impact on individual reactions during the first menstruation which have a negative impact including: depression, fear, confusion, concentration disorders, irritability, anxiety, difficulty sleeping, headache, flatulence (Mayasari, 2008)

Anxiety in dealing with menarche can occur due to lack information about menstruation. For reduce the anxiety is wrong one is to improve young women's knowledge about early menstruation by the way provision of health information on youth production (KRR), especially on menstruation (Proverawati and Misaroh, 2009). Providing information about menarche can be done through health education by health workers besides the teacher as teaching staff in the school can also provide information or knowledge to students about menarche. Parents also play a role in giving explanations to children about menstruation because they are the people closest to the child so that children can be better prepared and not feel anxious about-facing menarche or first menstruation.

\section{METHODS}

Study Design

This study design using pre experimental One group design with prepost-test design.

\section{Setting}

The study was conducted in SDIT Permata Mulia, Mojokerto Regency. 
Research Subject

The population in this study were students in grades $\mathrm{V}$ and VI at SDIT Permata Mulia, Mojokerto Regency who had not experienced menarche. The population in this study amounted to 28 respondents, the sample in this study, namely female students of grades V and VI at SDIT Permata Mulia, Mojokerto Regency who had not experienced menarche, sample selection is done by Non-Probability Sampling with Saturated Sampling type.

\section{Instruments}

The instrument for assessing anxiety in facing menarche was used the questionnaire.

\section{Data Analysis}

The data were analyzed using the Wilcoxon test with a significance level of 0.05 .

\section{Ethical Consideration}

This research has obtained permission from National Unity and Politics of Mojokerto Regency.

\section{RESULTS}

Level of Student Anxiety before Health Education is Provided about Menarche

Table 1. Level of Student Anxiety before Health Education is Provided about Menarche in SDIT Permata Mulia, Mojokerto Regency $(n=28)$.

\begin{tabular}{|c|c|c|c|c|c|c|c|c|c|c|c|c|}
\hline \multirow{3}{*}{$\begin{array}{c}\text { Age } \\
\text { (years) }\end{array}$} & \multicolumn{8}{|c|}{ Pre-Test } & & & \multicolumn{2}{|c|}{ Total } \\
\hline & \multicolumn{2}{|c|}{$\begin{array}{c}\text { Not } \\
\text { worried }\end{array}$} & \multicolumn{2}{|c|}{ Light } & \multicolumn{2}{|c|}{ Is being } & \multicolumn{2}{|c|}{ Weight } & \multicolumn{2}{|c|}{ Panic } & \multirow[b]{2}{*}{$\mathrm{f}$} & \multirow[b]{2}{*}{$\%$} \\
\hline & $f$ & $\%$ & $\mathrm{f}$ & $\%$ & $\mathrm{f}$ & $\%$ & $\mathrm{f}$ & $\%$ & $\mathrm{f}$ & $\%$ & & \\
\hline 11 & 0 & 0 & 4 & 14.3 & 8 & 28.6 & 7 & 25.0 & 0 & 0 & 19 & 67.9 \\
\hline 12 & 0 & 0 & 1 & 3.6 & 7 & 25.0 & 1 & 3.6 & 0 & 0 & 9 & 32.1 \\
\hline Total & 0 & 0 & 5 & 17.9 & 15 & 53.6 & 8 & 28.6 & 0 & 0 & 28 & 100 \\
\hline
\end{tabular}

Based on table 1 above, it was found that the respondents had moderate anxiety in the pre-test by the age of 11 years as many as 8 respondents $(28.6 \%)$.
The Level of Student Anxiety before being Given A Health Education about Menarche

Table 2. The Level of Student Anxiety before being Given A Health Education about Menarche in SDIT Permata Mulia, Mojokerto Regency $(\mathrm{n}=28)$.

\begin{tabular}{llcc}
\hline No. & $\begin{array}{c}\text { Anxiety } \\
\text { Level }\end{array}$ & $\begin{array}{c}\text { Frequency } \\
\text { (f) }\end{array}$ & $\begin{array}{c}\text { Percentage } \\
(\mathbf{\%})\end{array}$ \\
\hline 1 & Not & 8 & 28.6 \\
& worried & 16 & 57,1 \\
2 & Light & 4 & 14.3 \\
3 & Is being & 0 & 0 \\
4 & Weight & 0 & 0 \\
5 & Panic & 28 & 100 \\
\hline \multicolumn{2}{l}{ Total } & \multicolumn{2}{l}{ Sources: Primary Data of Questionnaire, 2018 }
\end{tabular}

Based on table 2 above showed the results after being given health education about menarche, most of the respondents as many as 16 respondents $(57.1 \%)$ with moderate anxiety levels.

The Effect of Health Education about Menarche on Anxiety

Table 3. The Effect of Health Education about Menarche on Anxiety in Facing Menarche at SDIT Permata Mulia, Mojokerto Regency $(n=28)$.

\begin{tabular}{cc}
\hline & Post-Test - Pre-Test \\
\hline $\mathrm{Z}$ & $-4,654^{\mathrm{a}}$ \\
Asymp. Sig. (2-tailed) & .000 \\
\hline Sources: Primary Data of Questionnaire, 2018
\end{tabular}

According to the table 3, it was found that the results of Wilcoxon Signed Ranks Test data obtained $\rho=0.00<\alpha=0.05, \mathrm{H}_{0}$ is rejected and $\mathrm{H}_{1}$ accepted, which means there is influence between a health education about menarche to anxiety in the face of menarche in female students in grades V and VI.

\section{DISCUSSION}

Based on the results of the study, it was found in table 4.4, showing that the level of student anxiety before being given health 
education was moderate anxiety, namely 15 female students $(53.6 \%)$.

A person's anxiety level is influenced by several factors, the first is the age factor. Based on table 4.1 most respondents $67.9 \%$ aged 11 years as many as 19 respondents and based on table 4.3 in the pre-test level of moderate anxiety most experienced by the age of 11 years as many as 8 respondents $(28.6 \%)$. Someone who has a younger age is more likely to experience anxiety disorders than someone who is older, but there are also those who argue the opposite (Varcolis, 2000). Anxiety is a symptom that often occurs and is very striking in menarche events which are then reinforced by the desire to reject the physiological process (Kartono, 2006). Anxiety is also influenced by gender. According to Ramaiah (2006) anxiety is more often experienced by women than men. Menarche occurs in women with a young age range, so the chances of someone facing menarche will experience anxiety disorders. Along with increasing age, experience about menstruation will also increase so that there will be no more interference due to anxiety.

The second factor that influences this research is the information factor. The anxiety experienced by respondents in this study is caused by a lack of information, this is in accordance with the data obtained in table 4.2 that $100 \%$ of students have not received information about menarche. According to Budiati \& Apriastuti (2012) If the child's ignorance of menstruation can make it difficult for children to accept menarche. $\mathrm{S}$ aat a woman experiences menstrual events, if the information acquired is not accompanied by the correct information, then there will be a wide variety of psychological problems and disorders of the female genital self (Kartono, 2006). Landis et al (Sulaeman, 2005) also suggested that the reaction of young women to first menstruation varies, it depends on the preparations of a young woman before her first menstruation. The preparations are in the form of information and knowledge related to menstruation. With minimal information about menarche will have an impact on the emergence of child anxiety in the face of menarche. Information about menarche is really needed by children to support children's readiness in facing menarche. Changes that occur during the first menstruation (menarche) cause the child to feel comfortable. Children usually do not know about changes that occur to him. Therefore, if not informed or not prepared properly about the changes that occur, one of them will have a negative impact, namely arising feeling of anxiety. In this study most of the respondents $(53.6 \%)$ experienced moderate anxiety.

Another factor that affects anxiety is environmental factors. In this case it can be in the environment at home and the environment in the school. Facing menstruation or first menstruation (menarche), a young woman needs to make behavioral adjustments. This adjustment requires surrounding support, especially support from parents (Sarwono, 2007). According to Jones (2005) information and knowledge about menstruation, ideally delivered by a mother to her teenage daughter, but not all mothers provide adequate information to their daughter and some mothers are reluctant to talk openly until their daughter has had her first menstruation. This will cause anxiety in young women, even the belief that menstruation appears something unpleasant. Anxiety is very much related to feelings of uncertainty and not empowered, in young women who experience menarche anxiety will can be reduced if the availability of health education services in schools and the increasing desire of teenagers to read books medicine (Burn, 2000). Increasing reading interest related to menarche and increasing adolescent knowledge about health problems, school is the most appropriate place because school is an extension of family in laying the 
foundation of behavior for the life of the next child, so the school plays a role in the process of delivering health information to adolescents (Notoatmodjo, 2007). The family environment and environment in the school are very supportive of the anxiety that children experience in facing menarche. An environment that is not taboo in discussing things about menarche will be able to help children prepare themselves in the face of changes that occur along with increasing age. Providing information from parents about first menstruation (Menarche) is needed by children and health education through school is a very effective activity in supporting children's readiness in facing menarche. If both of these things can go well, it will help the child to reduce his anxiety in the face of menarche.

From the results of the study found in table 4. 6 that most levels of anxiety after being given health education about menarche is mild, which is 16 students $(57.1 \%)$. The level of student anxiety tends to decrease because it has received information about menarche.

Menarche is the most important event in young women as a sign that the fertile cycle has begun. The arrival of menarche precisely makes some teenagers, scared and nervous because they think that blood menstruation is a disease, but some teenagers actually feel happy when getting menarche, especially those who already know about menarche (Rosidah, 2006). According to Santrock (2003) in girls who are experiencing menarche, will experience psychological conditions such as anxiety, stress, fear, depression due to physical changes that occur during menarche. Burns (2000) said that if girls had been told about menstruation before he really - really experience it maybe he will be happy when menstruation arrives, because thus he stepped toward maturity. Those who don't getting information about menstruation can be frightening when you see blood starting to come out of the vagina. Ellis in his book
Kartono (1992), mentions that there is one young woman commit suicide on the grounds that they suffer from a dirty disease, after being examined it turns out that the dirty disease in question is menstruation. From the survey he has done, teenagers get menstrual information from peers and few obtain information from the book - the book health.

From the theory described above, it can be seen that giving earlier information about menarche is very influential on the anxiety experienced by children in the face of menarche. Providing information earlier about menarche will reduce anxiety in the face of menarche. In providing information, the explanation given must be correct and correct in order to increase children's knowledge about menarche, providing inappropriate information will later add to children's fear and anxiety in the face of menarche. By giving the right information can increase knowledge about menarche, so that it will change the child's perception of initially negative menarche into a positive perception so that with a positive perception, the child will accept menarche as something normal from within and not consider menarche to be something to worry about. So that later it will have a good impact on its readiness to face menarche.

Based on table 4.8 on the Wilcoxon Signed Rank Test results obtained data $\rho=$ $0.00<\alpha=0.05$ then $H_{1 \text { is }}$ accepted which means there is an influence between health education about menarche against anxiety in facing menarche in students in grades $\mathrm{V}$ and VI at SDIT Permata Mulia.

Menarche is one sign that adolescents have experienced changes in themselves and also accompanied by various problems and changes in physical, biological, psychological and social, must be faced by adolescents because this is a very important period because it is a period of transition to adult. Psychological symptoms that are striking at menarche are anxiety and fear that are strong by the desire to reject these 
physiological processes. That the feelings of young women who experience menarche are beset by sadness and confusion (Kartono, 2006). According to Suryani et al (2010), girls who are not taught to consider menstruation as a normal body function can experience shame and dirty feelings during their first menstruation. Health education is an activity or effort to convey health messages to people, groups or individuals. With the hope that with the message, people, groups, or individuals can obtain knowledge about better health. Finally, this knowledge is expected to influence his behaviour. In other words, the existence of education can have an impact on my target goals (Notoatmodjo, 2007). Proverawati \& Misaroh (2009) argue that knowledge about menstruation can reduce anxiety in dealing with first menstruation or menarche. Dariyo (2004) also states that providing information on reproductive health (KRR) especially regarding menstruation can be given through counselling, so that the anxiety of young women on menarche can be reduced or even non-existent.

From the results obtained from existing research that there is influence between health education about menarche to anxiety in the face of menarche in sis wi class V and VI in the S DIT Banjaragung Desa Permata Mulia $P$ uri District of Mojokerto. This can be interpreted as health education about menarche indeed effective in reducing female anxiety in the face of menarche. Health education with one method such as counselling can be used as a means to provide information about menarche so that later it can increase student knowledge about menarche. With sufficient information and given as early as possible, it can reduce student anxiety in the face of menarche

\section{CONCLUSION}

Seeing the results of this study about health education about menarche can help in reducing female anxiety in the face of menarche, the role of parents and educators is needed in providing an explanation of menarche to children in grades $\mathrm{V}$ and VI aged 11-12 years including maintaining personal hygiene in genital, provide knowledge to students that menarche will occur in all women.

\section{SUGGESTIONS}

According the result of study, parents should be providing education on matters related to menarche such as expulsion of blood from his genitals, and provide education about personal hygiene in genital areas, besides that people do provide motivation and explain to children to children that every woman will experience menarche and it is a physiological thing. For students, they have been more prepared in the face of anxiety during menarche by knowing the signs of changes that occur during menarche such as the release of blood from the genitals during the first menstruation, increasing personal hygiene in genital areas, so that it can reduce anxiety.

\section{REFERENCES}

Burn, A. (2000). Empowering Women in the Field of Health. Yogyakarta: Esentria Medica Foundation.

Dariyo, Agus. (2004). Adolescent Development Psychology. Bogor: Ghalia Indonesia.

RI Ministry of Health. 2010. Collection of Adolescent Reproductive Health Material. Jakarta: Ministry of Health.

Hawari, D. (2008). Stress, Anxiety, and Depression Management. Jakarta: FKUI Publisher Hall.

Herawani et al. (2001). Health Education in Nursing. Jakarta: EGC.

Jones, DL. (2005). Every woman. Jakarta: Dela Pratasa.

Kartono, K. (2006). Women's Psychology: Getting to Know Women as Mothers and 
Grandmothers. Bandung: Mandar Forward.

Kusumawati, F., Hartono, Y. (2010). Textbook for Soul Nursing. Jakarta: Salemba Medika.

Mayasari. (2008). The Importance of the Role of Parents About Adolescent Children's Reproductive Health. Jakarta. Salemba Medika.

Mubarak, Wahid Iqbal. (2007). Health Promotion: An Introduction to Teaching and Learning in Education. Yogyakarta: Graha Ilmu.

Notoatmodjo, Soekidjo. (2003). Health Education and Behaviour. Jakarta: Rineka Cipta.

Notoatmodjo, Soekidjo. (2007). Promotion of Health and Behavioural Sciences. Jakarta: Rineka Cipta.

Nursalam. (2009). Concept and Application of Research Methodology in Nursing. Jakarta: Salemba Medika.

Perry \& Potter. (2005). Fundamental of Nursing; Concept, Process, and Practice. Jakarta: EGC.

Proverawati, A., Misaroh, S. (2009). Menarche, First Menstruation Full of Meanings. Yogyakarta: Nuha Medika.

Ramaiah, S. (2006). Overcoming Menstrual Disorders. Yogyakarta: Diglosia. Medika.

Rubianto. (2002). Adolescent Reproductive Health. Yogyakarta: Rineka Cipta.

Santrock, J. W. (2003). Adolescence: Adolescent Development. Jakarta: Arcan.

Sarwono, S. W. (2007). Adolescent Psychology. Jakarta: Raja Grafindo Persada.

Setiadi. (2007). Concept and Writing of Nursing Research. Yogyakarta: Graha Ilmu.
Sugiyono. (2010). Qualitative and Quantitative Research Methods $R$ $\& D$. Bandung: Alfabeta.

Sulaeman, D. (2005). Adolescent Psychology: Developmental Dimensions. Bandung: CV. Mandar Maju.

Suliha. (2002). Health Education in Nursing. Jakarta: Salemba Medika.

Suliswati et al. (2005). Basic Concept of Mental Health Nursing. Jakarta: EGC.

Suryani, E. (2010). Mother and Child Psychology. Yogyakarta: Fitramaya.

Stuart, G. W. (2006). Pocket Nursing Book. Jakarta: EGC

Varcoralis, E. M. (2000). Psychiatric Nursing Clinical Guide: Tools \& Tools Diagnosis. Philadelphia: WB Saunders Company.

Videbeck, S. J. (2008). Textbook for Soul Nursing. Jakarta: EGC.

Waryana. (2010). Reproductive Nutrition. Yogyakarta: Rihama Library.

Wiknjosastro. (2005). Young Women Puberty. Central Jakarta: Salemba Medika.

Cite This Article As: Sari, S.M., \& Effendy, H.V. The Effect of Health Education about Menarche on Anxiety in Facing Menarche in 5th and 6th Grade Students. Nurse and Health: Jurnal Keperawatan 2019; 8(1): 43-49. 